\title{
A Conceptual Model to Measure the Impact of Consumer Behaviour on E- Retailing in India
}

\author{
Raja Sarkar ${ }^{1}$, Dr. Sabyasachi Das ${ }^{2}$ \\ 1Ph.D. Scholar, Department of Business Administration, Utkal University, Bhubaneswar, Odisha \\ ${ }^{2}$ Lecturer, IMBA, Department of Business Administration, Utkal University, Bhubaneswar, Odisha
}

\begin{abstract}
$21^{\text {st }}$ century is the era of information technology. Be it social networking, banking, ticket booking or e-retailing, the presence of information technology is ubiquitous in our day-to-day affairs. IT has transcended the physical distance between the service providers and the service receivers. It has also provided the consumers the much needed convenience and offered them competitive price for various products and services. In this context, eretailing has become a major shopping medium for customers specially the younger generations. The tech savvy young generation has taken to e-retailing like a fish takes to water. Even the older generations are becoming comfortable with the use of information technology for shopping purpose. India despite being a late starter, has become a major force in e-retailing and managed to achieve the tag of the fastest growing market in this category within a very short period. Apart from the home grown Flipkart, Snapdeal, Paytm, Shopclues, the largest e-tailer in the world Amazon has also made it into the country. Top retailers like Walmart and Alibaba have picked up major stakes in various e-tailers. The competition has become intense with large discounts and large assortment of products the order of the day. In this context, it has become essential for e-tailers to gauge the consumer behaviour to effectively target them. The present study is an effort to find out the various essential factors impacting e-retail purchase in India and develop a conceptual model for the same.
\end{abstract}

Keywords :E-retail, Information technology, Factor Analysis, Constructs, Conceptual model

\section{INTRODUCTION}

Online shopping is on a high growth trajectory due to the massive response of people. The forecast doesn't indicate towards any change in this trend in the foreseeable future and is expected to grow at an even faster pace. Customers are enjoying the convenience of shopping from home and with the easy availability of devices capable of accessing internet and plunging data tariffs, more and more number of people will be encouraged to adopt this medium of shopping in near future. With the advancement in the field of networking, multimedia and data processing, e-retailing has brought in new business opportunities for companies. They are spending billions to find the perfect business model to attract customers and bring in revenues. Apart from convenience, e-retailing offers customers additional benefits like larger choice of products, ability to interact and exchange ideas using online communities so on. Both companies and customers have recognized these benefits and gradually, shopping using e-retailing sites is becoming an integral part of people's daily life. The revolution in the field of internet has dramatically changed the way customers search and use information. Internet, 
which was conceptualized as a medium to gather information has become a vital place to conduct business.

The literature review has been carried out related to the area of e-retailing consumer behaviour. There have been very few studies carried out related to consumer behaviour in e-retailing in the Indian context. Detailed search of literature didn't reveal too many research works in this area in the Indian context. As a result, the researcher was forced to review literatures related to foreign countries in this area. Under the circumstances, it is well understood that there is a need for an extensive and detailed study analyzing various behavioural aspects impacting e-retailing consumer behaviour in the Indian context.Through this research work, the researcher expects to understand the various behavioural aspects of online shoppers impacting the adoption of shopping using e-retailing sites.

\section{Objectives:}

i)

To develop constructs to measure the impact of consumer behaviour on e-retailing in Indian context

ii) To test the reliability and validity of the constructs

iii) To develop a conceptual model for further study

\section{Review of literature:}

Karayanni (2003) carried out a comparative study to find out the factors differentiating online shoppers from non shoppers. The major factors found to be the key were web-shopping motives related to time efficiency, availability of 24 hour shopping and avoidance of queues during shopping. The study also found lack of trust on e-retailing to be a negative factor of e-retailing behaviour.
Kim \&Eom (2002) did a study to find out the significant factors impacting the intention towards eretailing. They found convenience, dependable shopping, reliability of retailers, additional information and product perception as the important factors impacting e-retailing intention.

Hirst \& Omar (2007) carried out a study to assess the apparel shopping behaviour of women on the internet where they found convenience, usefulness, ease of use and efficiency to have positive impact on e-retailing.

Vijayasarathy (2001) carried out a study to find out the factors impacting attitude and intention to use eretailing. The study revealed that integrated factors related to web or e-retailing aids could explain consumer e-retailing behaviour better.

\section{i) Perceived Usefulness}

Chu \& Lu (2007) carried out a study to understand the factors impacting online music purchase intention in Taiwan. They found that perceived usefulness had a significant impact on online music purchase intentionMangin et al. (2011) used the Technology acceptance model to understand the impact of perceived usefulness on adoption of online banking services in Canadian banking environment. They found perceived usefulness to be an important factor of adoption of online banking. According to an empirical research carried out by Liao \& Shi (2009), perceived usefulness had a positive influence on consumer attitude towards online shopping adoption.

\section{ii) Perceived Ease of Use}

Ramayah\& Ignatius (2005) found evidence to suggest that perceived ease of use had a positive impact on behavioural intention of e-retailing. Jisoo (2015) carried out a study on improving user interaction in interactive TV based on ethnographic insights from real life problems where perceived ease of use was found to have a significant impact on perceived 
usefulness. Davis et al. (1989) in their study on comparison of two theoretical models regarding user acceptance of computer technologyfound perceived ease of use to have a significant impact on perceived usefulness and attitude.

\section{iii) Perceived Enjoyment}

Sun \& Zhang (2006) tested two alternative models to find out the relationship between perceived ease of use and perceived enjoyment where the impact of perceived enjoyment on perceived ease of use was found to be stronger than the other way round. Davis et al. (1992) found intrinsic enjoyment to be a direct determinant of user acceptance online. Jarvenpaa\& Todd (1997) found perceived enjoyment to have a significant impact on attitude and intention to shop online.

\section{iv) Perceived Risk}

Clemes et al. (2014) found perceived risk to be an important factor determining e-retailing adoption. According to Zhao \& Li (2012), perception of higher risk towards e-retailing among customers results in significant negative impact on attitude and intention to shop online. Alreck\& Settle (2002) found that due to limited access to product and sales people, perceived risk in e-retailing was far higher which was adversely impacting purchase via internet.

\section{v) Web Aesthetics}

An empirical study carried out by Huang (2003) found that perceived complexity of a website had a negative influence on pleasure. Lindguard et al. (2003) in their study on user satisfactionfound that highly appealing websites had an impact on satisfaction of online users. Van der Heijden (2003) carried out a study to find out factors impacting usage of websiteswhich showed that online visual attractiveness which was the degree to which someone believed that a website was appealing aesthetically to the eyes, had a favourable impact on the intention to use a website.

\section{vi) Attitude and Intention}

Laroche (2002) carried out a study on consumer brand choice where it was found that consumers' intention to buy a particular brand not only was impacted by the attitude towards that particular brand, but also by the attitude towards other considered brands. According to Chen (2007), attitude of consumers to purchase organic food has a positive impact on the intention to purchase organic food. Thogersen\&Ölander (2006) did a panel study on the dynamic interaction of personal norms and environment-friendly buying behavior where they found attitude to be a vital predictor of intention to consume organic food in case of vegetables and fruits.

vii) Impact of Demographic variables on Attitude and Intention

a) Gender

Sebastianelli et al. (2008) in their study on perceived quality of e-retailing, categorized products into three categories- search, experience and credence. They found that males tend to purchase search products more whereas female affinity is higher towards purchasing experience products. Hasan (2010) segregated attitude into three types- cognitive, affective and behavioral. According to him, in case of cognitive attitude, males found e-retailing to be more useful as a shopping platform than their female counterparts. As a result, females also displayed less positive affective attitude towards e-retailing.A study conducted by Flavian et al. (2011) showed that quality images had the ability to increase female satisfaction which resulted in improved purchase intention whereas in case of males despite of increased satisfaction, it didn't result in improved purchase intention. 


\section{b) Age}

Goldsmith \& Goldsmith (2002) carried out a study to understand the factors impacting online apparel buying behaviour of consumers where they found that age didn't have any impact on buying apparels online. According to a study on attitude and age differences conducted by Sorce et al. (2005), older online shoppers managed to find far lesser number of useful products online compared to the younger shoppers. They also found differences in attitude based on age. Dholakia \&Uusitalo (2002) carried out a study on consumer characteristics of electronic stores where theyfound that perception of hedonic benefit was higher among older individuals for offline shopping compared to younger people.

\section{c) Income}

Lohse et al. (2000) commented that income didn't have any impact on if someone purchases online or not. But they also added that income had an impact on online spending. The more one's household income, the more they spend online. Iyer\& Eastman (2004) in their study on attitude towards the internet found significant influence of income on e-retailing. According to them, people with higher income tend to be users of internet and online shoppers. Sim \& Koi (2002) carried out a study on Singapore's internet shoppers and their impact on shopping patterns where they found that people with higher income shopped online more often.

\section{d) Educational Qualification}

Fram\& Grandy (1997) carried out a study on internet shoppers where education was frequently found to be impacting e-retailing purchase. Sultan \&Henrichs (2000) in their study on consumer preferences for internet services reported that education had a significant influence on e-retailing. According to Burke (2002), consumers with better education were more comfortable using non store shopping channels like internet and catalogues to search for products, gather product information and make purchases.

\section{e) Internet Experience}

Shim et al. (2001) conducted a study where they found direct and indirect relationships between previous internet purchase experience and online purchase intention. According to Koyunchu\& Lien (2003), prior internet experience reduced the time needed to navigate websites and search for information resulting in higher possibility of online purchase. Verplanken et al. (1998) saidthat prior experience enhances the affective component of one's attitude.

\section{Research Methodology:}

\section{i) Research Method}

The present study is a quantitative research in nature. Since this study was carried out to develop a conceptual model for further study, the inductive approach was used for the same.

\section{ii) Research Design}

The present research work is exploratory in nature in the initial part. Once the insights of the problem were gained, it was verified and conclusive research was used to quantify it. Descriptive study was carried out subsequently to meet the conclusive research requirements. Expert opinion was used to frame the research instrument.

\section{iii) Sampling Design}

Purposive sampling has been used to collect data in this study. Keeping in mind that majority of online shoppers are younger, more representation was given to them during selection of samples.

\section{iv) Data Collection Method}

Primary data has been used in the study. For investigation and data collection purpose, survey method has been used which is quite common in behavioural and marketing researches. Data was 
collected using structured questionnaire as an instrument, which was created using the Google Forms programme. All the questions in the questionnaire were strictly answerable and hence there were no receipt of incomplete questionnaire. The questionnaires were distributed using strictly online method via e-mail and Facebook. Basic demographic data was collected using nominal scale and behavioural aspects were recorded using likert scale. The collected data was quantitative in nature.

\section{v) Sample Size}

According to Gorsuch (1983) and Kline (1994), minimum 100 subjects are required for sampling purpose to carry out an exploratory factor analysis. Hence, for the present study, data from total 108 respondents were collected. Samples were collected from Bhubaneswar and Kolkata, which are the capital cities of the states of Odisha and West Bengal respectively.

Table-1: Original items adapted for the study and their sources

\begin{tabular}{|c|c|c|}
\hline Factors & Items & Sources \\
\hline \multirow{6}{*}{$\begin{array}{l}\text { Perceived } \\
\text { Usefulness }\end{array}$} & $\begin{array}{l}\text { Using CHART-MASTER in my job would enable me to accomplish } \\
\text { tasks more quickly }\end{array}$ & \multirow{6}{*}{ Davis (1989) } \\
\hline & Using CHART-MASTER would improve my job performance & \\
\hline & Using CHART-MASTER in my job would increase my productivity & \\
\hline & $\begin{array}{l}\text { Using CHART-MASTER would enhance my effectiveness on the } \\
\text { job }\end{array}$ & \\
\hline & Using CHART-MASTER would make it easier to do my job & \\
\hline & I would find CHART-MASTER useful in my job & \\
\hline \multirow{6}{*}{$\begin{array}{l}\text { Perceived Ease } \\
\text { of Use }\end{array}$} & Learning to operate CHART-MASTER would be easy for me & \multirow{6}{*}{ Davis (1989) } \\
\hline & $\begin{array}{l}\text { I would find it easy to get CHART-MASTER to do what I want it to } \\
\qquad \text { do }\end{array}$ & \\
\hline & $\begin{array}{l}\text { My interaction with CHART-MASTER would be clear and } \\
\text { understandable }\end{array}$ & \\
\hline & I would find CHART-MASTER to be flexible to interact with & \\
\hline & $\begin{array}{l}\text { It would be easy for me to become skillful at using CHART- } \\
\text { MASTER }\end{array}$ & \\
\hline & I would find CHART-MASTER easy to use & \\
\hline \multirow{4}{*}{$\begin{array}{l}\text { Perceived } \\
\text { Enjoyment }\end{array}$} & Enjoyable-disgusting & \multirow{4}{*}{$\begin{array}{c}\text { Van der } \\
\text { Heijden (2004) }\end{array}$} \\
\hline & Exciting-dull & \\
\hline & Pleasant-unpleasant & \\
\hline & Interesting-boring & \\
\hline \multirow{4}{*}{ Perceived Risk } & Financial risk & \multirow{4}{*}{$\begin{array}{c}\text { Peter } \\
\text { \&Tarpey(1975); } \\
\text { Cheng et al. }\end{array}$} \\
\hline & Performance risk & \\
\hline & Social risk & \\
\hline & Time risk & \\
\hline
\end{tabular}




\begin{tabular}{|c|c|c|}
\hline & Privacy risk & $(2013)$ \\
\hline \multirow{4}{*}{ Visual Appeal* } & The Web site is pleasing to look at & \multirow{4}{*}{ Cai et al. (2008) } \\
\hline & I like the look and feel of the web site & \\
\hline & The Web site is visually appealing & \\
\hline & The visual design of the Web site is attractive & \\
\hline \multirow{4}{*}{ Organization* } & The design of Web site is harmonious & \multirow{4}{*}{ Cai et al. (2008) } \\
\hline & The layout of the Web site is intuitive & \\
\hline & The Web site has logically organized elements & \\
\hline & $\begin{array}{l}\text { The layout of the Web site was designed in a manner I am } \\
\text { accustomed to }\end{array}$ & \\
\hline \multirow{5}{*}{ Attitude } & $\begin{array}{l}\text { All things considered, my using spreadsheets in accomplishing } \\
\text { various tasks in industry was good }\end{array}$ & \multirow{5}{*}{$\begin{array}{l}\text { Al-Gahtani\& } \\
\text { King (1999) }\end{array}$} \\
\hline & $\begin{array}{l}\text { All things considered, my using spreadsheets in accomplishing } \\
\text { various tasks in industry was wise }\end{array}$ & \\
\hline & $\begin{array}{l}\text { All things considered, my using spreadsheets in accomplishing } \\
\text { various tasks in industry was favourable }\end{array}$ & \\
\hline & $\begin{array}{l}\text { All things considered, my using spreadsheets in accomplishing } \\
\text { various tasks in industry was beneficial }\end{array}$ & \\
\hline & $\begin{array}{l}\text { All things considered, my using spreadsheets in accomplishing } \\
\text { various tasks in industry was positive }\end{array}$ & \\
\hline \multirow{3}{*}{ Intention } & $\begin{array}{l}\text { I will do most of my future purchase for [product] with this Web } \\
\text { site }\end{array}$ & \multirow[t]{3}{*}{ Cai et al. (2008) } \\
\hline & I will recommend this Web site to friends, neighbors, and relatives & \\
\hline & I will use this Web site the very next time I need to shop & \\
\hline
\end{tabular}

* Cai et al. (2008) proposed a two dimensional structure of Web site Aesthetics by taking Visual Appeal and Organization as two of its components

Table-2 :Demographic Characteristics of the sample

\begin{tabular}{|c|c|c|c|}
\hline Variables & Category & Frequency & Percent (\%) \\
\hline \multirow{2}{*}{ Gender } & Male & 69 & 63.9 \\
\cline { 2 - 4 } & Female & 39 & 36.1 \\
\cline { 2 - 4 } & Total & 108 & 100.0 \\
\hline & Less than 25 & 28 & 25.9 \\
\hline
\end{tabular}




\begin{tabular}{|c|c|c|c|}
\hline \multirow{4}{*}{ Age } & Between 25 and 35 & 57 & 52.8 \\
\hline & Between 35 and 50 & 16 & 14.8 \\
\hline & More than 50 & 7 & 6.5 \\
\hline & Total & 108 & 100.0 \\
\hline \multirow{5}{*}{$\begin{array}{l}\text { Educational } \\
\text { Qualification }\end{array}$} & Class 12 & 6 & 5.6 \\
\hline & Diploma & 19 & 17.6 \\
\hline & Graduation & 50 & 46.3 \\
\hline & Post graduation or higher & 33 & 30.5 \\
\hline & Total & 108 & 100.0 \\
\hline \multirow{5}{*}{ Monthly Income } & Less than Rs. 10000 & 36 & 33.3 \\
\hline & Between Rs.10000 and Rs.30000 & 33 & 30.6 \\
\hline & Between Rs.30000 and Rs.50000 & 22 & 20.4 \\
\hline & More than Rs.50000 & 17 & 15.7 \\
\hline & Total & 108 & 100.0 \\
\hline \multirow{5}{*}{ Internet Experience } & Less than 1 year & 4 & 3.7 \\
\hline & Between $1-3$ years & 8 & 7.4 \\
\hline & Between 3-5 years & 16 & 14.8 \\
\hline & More than 5 years & 80 & 74.1 \\
\hline & Total & 108 & 100.0 \\
\hline
\end{tabular}

\section{Content validity:}

The items considered for the study are adapted versions of various established and validated scales. After making necessary modifications within the items to suit the present study, they were shown to some subject experts for their opinions regarding the suitability, wordings and completeness of the same. According to their suggestions, further modifications were carried out within the items to achieve the final set of items. 


\section{Final items for the study:}

The following 37 adapted items were used in the study:

Item-1: Using e-retailing as a shopping medium enables me to accomplish my shopping tasks more quickly

Item-2: Using e-retailing as a shopping medium improves my shopping performance

Item-3: Using e-retailing sites for shopping increases my productivity

Item-4: Using e-retailing sites for shopping enhances my shopping effectiveness

Item-5: Using e-retailing sites makes it easierfor meto shop

Item-6: I find e-retailing sites useful for shopping

Item-7: Learning to operate e-retailing sites was easy for me

Item-8: I find it easy to get the e-retailing sites to do what I want it to do

Item-9: My interaction with e-retailing sites is clear and understandable

Item-10: I find the e-retailing sites flexible to interact with

Item-11: It is easy for me to become skilful at using the e-retailing sites

Item-12: I find e-retailing sites easy to use

Item-13: E-retailing sites are enjoyable

Item-14: E-retailing sites are exciting

Item-15: E-retailing sites are pleasant
Item-16: E-retailing sites are interesting

Item-17: Using e-retailing sites could lead to financial loss for me

Item-18: Products purchased using e-retailing sites might not perform as expected

Item-19: Society might not approve my purchases from e-retailing sites

Item-20: Using e-retailing sites could lead to waste of time due to time required for product exchanges and delivery of products

Item-21: Using e-retailing sites could lead to loss of privacy

Item-22: E-retailing sites are pleasing to look at

Item-23: I like the look and feel of e-retailing sites

Item-24: E-retailing sites are visually appealing

Item-25: The visual designs of e-retailing sites are attractive

Item-26: The designs of e-retailing sites are harmonious

Item-27: The layouts of e-retailing sites are intuitive

Item-28: The e-retailing sites have logically organized elements

Item-29: The layout of e-retailing sites are designed in a manner I am accustomed to

Item-30: All things considered,using e-retailing sites for shopping is good

Item-31: All things considered, myusing e-retailing sites for shopping is wise 
Item-32: All things considered,my using e-retailing sites for shopping is favourable

Item-33: All things considered,my using e-retailing sites for shopping is beneficial

Item-34: All things considered,my using e-retailing sites for shopping is positive

Item-35: I will do most of my future shopping from e-retailing sites

Item-36: I will recommend e-retailing sites to friends, neighbours, and relatives

Item-37: I will use e-retailing sites the very next time I need to shop

\section{Exploratory factor analysis:}

To understand the various factors influencing customer's attitude towards e-retailing, the responses of respondents were examined with the help of factor analysis using principal component analysis method with Promax rotation. According to McDonald (1999), in case of actual application, rarely factors underlying tests can be truly uncorrelated. Hence it was suggested that the most appropriate rotation method would be oblique rotation. Promax raises the loadings to a power of four which ultimately offers better correlations among the factors and develops a simple structure. (Gorsuch, 1983)

There are three objectives of carrying out factor analysis; (i) to unravel the factors underlying the data, (ii) to test the validity (unidimensionality, convergent and discriminant validity) of the factors, and (iii) to calculate the factor scores through subsequent analyses.

Upon factor analysis, two of the items namely Item 29 and Item 31 were found to have cross loadings on two factors each since both the items had loaded higher than 0.32 on both those factors (Costello \& Osborne, 2005) and the difference being less than 0.2 between the loadings in each case and thus insignificant (Cudeck\& O'Dell, 1994). Hence, these two items were dropped from further analysis and the exploratory factor analysis was repeated in the absence of the two above mentioned items.

According to Lai et al. (2004), we need to repeat EFA until we manage to drop all the deletable items. Hence, EFA was repeated with the remaining 35 items. The various results obtained from the second exploratory factor analysis are given below:

Table-2 :KMO and Bartlett's Test

\begin{tabular}{|c|c|c|}
\hline \multicolumn{2}{|c|}{ Kaiser-Meyer-Olkin Measure of Sampling Adequacy. } & .846 \\
\hline \multirow{3}{*}{ Bartlett's Test of Sphericity } & Approx. Chi-Square & 1999.839 \\
\hline & $\mathrm{df}$ & 595 \\
\hline & Sig. & .000 \\
\hline
\end{tabular}

The Kaiser-Meyer-Olkin (KMO) measures the sampling adequacy, which determines if the responses received using the sample is adequate, or not. The above table shows the value of KMO measure of sampling adequacy statistics to be 0.846 which is above the stipulated lower limit of 0.7 and hence acceptable. (Kaiser, 1974). Apart from that Bartlett's test of Sphericity value was found to be 1999.839 which is also significant $(\mathrm{p}<0.05)$. Hence, the sample is amenable to factor analysis. 
Table-3 :Communalities

\begin{tabular}{|c|c|c|}
\hline & Initial & Extraction \\
\hline Item1 & 1.000 & .693 \\
Item2 & 1.000 & .596 \\
Item3 & 1.000 & .740 \\
Item4 & 1.000 & .598 \\
Item5 & 1.000 & .735 \\
Item6 & 1.000 & .671 \\
Item7 & 1.000 & .559 \\
Item8 & 1.000 & .861 \\
Item9 & 1.000 & .751 \\
Item10 & 1.000 & .568 \\
Item11 & 1.000 & .729 \\
Item12 & 1.000 & .857 \\
Item13 & 1.000 & .853 \\
Item14 & 1.000 & .694 \\
Item15 & 1.000 & .603 \\
Item16 & 1.000 & .852 \\
Item17 & 1.000 & .805 \\
Item18 & 1.000 & .599 \\
Item19 & 1.000 & .641 \\
Item20 & 1.000 & .526 \\
Item21 & 1.000 & .547 \\
Item22 & 1.000 & .522 \\
Item23 & 1.000 & .573 \\
Item24 & 1.000 & .429 \\
Item25 & 1.000 & .567 \\
Item26 & 1.000 & .628 \\
Item27 & 1.000 & .562 \\
Item28 & 1.000 & .592 \\
Item30 & 1.000 & .658 \\
Item32 & 1.000 & .588 \\
Item33 & 1.000 & .521 \\
Item34 & 1.000 & .737 \\
Item35 & 1.000 & .756 \\
Item36 & 1.000 & .591 \\
Item37 & 1.000 & \\
\hline
\end{tabular}

Extraction Method: Principal Component Analysis. 
Table-4: Total Variance Explained

\begin{tabular}{|c|c|c|c|c|c|c|c|}
\hline \multirow[t]{2}{*}{ Component } & \multicolumn{3}{|c|}{ Initial Eigenvalues } & \multicolumn{3}{|c|}{$\begin{array}{l}\text { Extraction Sums of Squared } \\
\text { Loadings }\end{array}$} & \multirow{2}{*}{$\begin{array}{c}\text { Rotation } \\
\text { Sums of } \\
\text { Squared } \\
\text { Loadings } \\
\text { Total }\end{array}$} \\
\hline & Total & $\begin{array}{c}\% \text { of } \\
\text { Variance }\end{array}$ & $\begin{array}{l}\text { Cumulativ } \\
\text { e } \%\end{array}$ & Total & $\begin{array}{c}\% \text { of } \\
\text { Variance }\end{array}$ & $\begin{array}{l}\text { Cumulat } \\
\text { ive } \%\end{array}$ & \\
\hline 1 & 7.263 & 20.751 & 20.751 & 7.263 & 20.751 & 20.751 & 4.398 \\
\hline 2 & 3.868 & 11.051 & 31.803 & 3.868 & 11.051 & 31.803 & 3.986 \\
\hline 3 & 3.659 & 10.454 & 42.257 & 3.659 & 10.454 & 42.257 & 3.761 \\
\hline 4 & 3.012 & 8.606 & 50.863 & 3.012 & 8.606 & 50.863 & 3.164 \\
\hline 5 & 2.637 & 7.534 & 58.397 & 2.637 & 7.534 & 58.397 & 2.934 \\
\hline 6 & 1.811 & 5.174 & 63.571 & 1.811 & 5.174 & 63.571 & 2.834 \\
\hline 7 & 1.435 & 4.100 & 67.671 & 1.435 & 4.100 & 67.671 & 2.608 \\
\hline 8 & .908 & 2.594 & 70.266 & & & & \\
\hline 9 & .835 & 2.386 & 72.651 & & & & \\
\hline 10 & .802 & 2.291 & 74.943 & & & & \\
\hline 11 & .768 & 2.194 & 77.137 & & & & \\
\hline 12 & .712 & 2.034 & 79.171 & & & & \\
\hline 13 & .653 & 1.866 & 81.037 & & & & \\
\hline 14 & .612 & 1.749 & 82.786 & & & & \\
\hline 15 & .584 & 1.669 & 84.454 & & & & \\
\hline 16 & .533 & 1.523 & 85.977 & & & & \\
\hline 17 & .512 & 1.463 & 87.440 & & & & \\
\hline 18 & .491 & 1.403 & 88.843 & & & & \\
\hline 19 & .453 & 1.294 & 90.137 & & & & \\
\hline 20 & .412 & 1.177 & 91.314 & & & & \\
\hline 21 & .384 & 1.097 & 92.411 & & & & \\
\hline 22 & .359 & 1.026 & 93.437 & & & & \\
\hline 23 & .312 & .891 & 94.329 & & & & \\
\hline 24 & .293 & .837 & 95.166 & & & & \\
\hline 25 & .264 & .754 & 95.920 & & & & \\
\hline 26 & .236 & .674 & 96.594 & & & & \\
\hline 27 & .213 & .609 & 97.203 & & & & \\
\hline 28 & .192 & .549 & 97.751 & & & & \\
\hline 29 & .171 & .489 & 98.240 & & & & \\
\hline 30 & .146 & .417 & 98.657 & & & & \\
\hline 31 & .128 & .366 & 99.023 & & & & \\
\hline 32 & .103 & .294 & 99.317 & & & & \\
\hline 33 & .099 & .283 & 99.600 & & & & \\
\hline
\end{tabular}




\begin{tabular}{|c|c|c|c|c|c|}
\hline 34 & .087 & .249 & 99.849 & & \\
\hline 35 & .053 & .151 & 100.000 & & \\
\hline Extraction Method: Principal Component Analysis. & & \\
\hline
\end{tabular}

Communalities for each factor are presented in Table-3. Communalities show how much of the variance in the variables have been accounted for by the extracted factors. The above table shows that the extracted values for all the items are more than 0.4 which is the minimum acceptable score for the same (Fabrigar et al., 1999). Hence, all the items were retained for subsequent steps of factor analysis.

The Total Variance explained is presented in Table-4. Eigen value reflects the number of extracted factors whose sum should be equal to number of items which are subjected to factor analysis. The final decision to arrive at the number of factors to be retained was taken on the basis of latent root criterion which is variables depicting Eigen Values greater than 1 (Kaiser, 1960). Keeping this criteria in mind, seven rotated factors were extracted which together explains $67.671 \%$ of the total variance which is higher than the acceptable variance limit of 60 per cent (Zikmund et al., 2010). Eigen values for factors F1 to F7 are 7.263, 3.868, 3.659, 3.012, 2.637, 1.811, and 1.435 respectively. Subsequently, appropriate names were assigned to all the seven dimensions extracted based on the various items representing each one of them.

Table-5:Pattern Matrix ${ }^{\mathrm{a}}$

\begin{tabular}{|c|c|c|c|c|c|c|c|}
\hline & \multicolumn{7}{|c|}{ Component } \\
\hline & 1 & 2 & 3 & 4 & 5 & 6 & 7 \\
\hline Item 35 & .844 & & & & & & \\
\hline Item37 & .770 & & & & & & \\
\hline Item36 & .743 & & & & & & \\
\hline Item 26 & & .845 & & & & & \\
\hline Item 23 & & .821 & & & & & \\
\hline Item22 & & .785 & & & & & \\
\hline Item 25 & & .749 & & & & & \\
\hline Item 24 & & .710 & & & & & \\
\hline Item 28 & & .695 & & & & & \\
\hline Item 27 & & .661 & & & & & \\
\hline Item3 & & & .827 & & & & \\
\hline Item5 & & & .812 & & & & \\
\hline Item 1 & & & .802 & & & & \\
\hline Item6 & & & .799 & & & & \\
\hline Item4 & & & .692 & & & & \\
\hline
\end{tabular}




\begin{tabular}{|c|c|c|c|c|c|}
\hline $\begin{array}{l}\text { Item2 } \\
\text { Item34 } \\
\text { Item30 } \\
\text { Item33 } \\
\text { Item32 } \\
\text { Item17 } \\
\text { Item19 } \\
\text { Item18 } \\
\text { Item20 } \\
\text { Item21 } \\
\text { Item16 } \\
\text { Item13 } \\
\text { Item14 } \\
\text { Item15 } \\
\text { Item12 } \\
\text { Item8 } \\
\text { Item } 9 \\
\text { Item11 } \\
\text { Item7 } \\
\text { Item10 }\end{array}$ & .581 & $\begin{array}{l}.841 \\
.768 \\
.686 \\
.593\end{array}$ & $\begin{array}{l}.879 \\
.788 \\
.751 \\
.674 \\
.556\end{array}$ & $\begin{array}{l}.876 \\
.873 \\
.796 \\
.667\end{array}$ & $\begin{array}{l}.900 \\
.878 \\
.823 \\
.804 \\
.643 \\
.636\end{array}$ \\
\hline
\end{tabular}

Extraction Method: Principal Component Analysis.

Rotation Method: Promax with Kaiser Normalization.

a. Rotation converged in 7 iterations.

The objective of rotation is to reduce the number of factors on which the variables under investigation have high loadings. It only makes the interpretation of analysis easier without changing anything (Osborne \& Costello, 2009).

The lower limit for item loadings was set at .30 since according to several researchers, anything less than that should not be considered (Armor, 1974). 
Table-6:Component Correlation Matrix

\begin{tabular}{|c|c|c|c|c|c|c|c|}
\hline Component & 1 & 2 & 3 & 4 & 5 & 6 & 7 \\
\hline 1 & 1.000 & .160 & .112 & .160 & -.135 & .205 & .415 \\
2 & .160 & 1.000 & .103 & .246 & -.236 & .378 & .117 \\
3 & .112 & .103 & 1.000 & .154 & -.151 & .128 & .118 \\
4 & .160 & .246 & .154 & 1.000 & -.277 & .276 & .132 \\
5 & -.135 & -.236 & -.151 & -.277 & 1.000 & -.209 & -.197 \\
6 & .205 & .378 & .128 & .276 & -.209 & 1.000 & .169 \\
7 & .415 & .117 & .118 & .132 & -.197 & .169 & 1.000 \\
\hline
\end{tabular}

Extraction Method: Principal Component Analysis

Rotation Method: Promax with Kaiser Normalization

\section{Factors extracted:}

The 7 factors extracted are given below

\section{Factor-1: Intention to purchase Online}

This factor contains three items- Item 35, Item 37, Item 36 explaining $20.751 \%$ of variance in the data, with the Eigen value of 7.263. The items associated with this factor are given below:

INT1: I will do most of my future shopping from e-retailing sites

INT2: I will use e-retailing sites the very next time I need to shop

INT3: I will recommend e-retailing sites to friends, neighbours, and relatives

\section{Factor-2: Web Aesthetics}

This factor contains eight items- Item 26, Item 23, Item 22, Item 25, Item 24, Item 29, Item 28, Item 27 explaining $11.051 \%$ of variance in the data, with the Eigen value of 3.868. The items associated with this factor are given below:

WA1: The designs of e-retailing sites are harmonious

WA2: I like the look and feel of e-retailing sites

WA3: E-retailing sites are pleasing to look at

WA4: The visual designs of e-retailing sites are attractive

WA5: E-retailing sites are visually appealing

WA6: The e-retailing sites have logically organized elements

WA7: The layouts of e-retailing sites are intuitive

\section{Factor-3: Perceived Usefulness}

This factor contains six items- Item 3, Item 5, Item 6, and Item 1, Item 4, Item 2 explaining 10.454\% variance in the data, with the Eigen value of 3.659. The items associated with this factor are given below:

PU1: Using e-retailing sites for shopping increases my productivity

PU2: Using e-retailing sites makes it easierfor meto shop

PU3: Using e-retailing as a shopping medium enables me to accomplish my shopping tasks more quickly

PU4: I find e-retailing sites useful for shopping 
PU5: Using e-retailing sites for shopping enhances my shopping effectiveness

PU6: Using e-retailing as a shopping medium improves my shopping performance

\section{Factor-4: Attitude towards E-retailing}

This factor contains five items- Item 31, Item 34, Item 30, Item 33, Item 32 explaining $8.606 \%$ of variance in the data, with the Eigen value of 3.012. The items associated with this factor are given below:

ATT1: All things considered,my using e-retailing sites for shopping is positive

ATT2: All things considered,using e-retailing sites for shopping is good

ATT3: All things considered,my using e-retailing sites for shopping is beneficial

ATT4: All things considered,my using e-retailing sites for shopping is favourable

\section{Factor-5: Perceived Risk}

This factor contains five items- Item 17, Item 19, Item 18, Item 20, and Item 21 explaining 7.534\% of variance in the data, with the Eigen value of 2.637. The items associated with this factor are given below:

PR1: Using e-retailing sites could lead to financial loss for me

PR2: Society might not approve my purchases from e-retailing sites

PR3: Products purchased using e-retailing sites might not perform as expected

PR4: Using e-retailing sites could lead to waste of time due to time required for product exchanges and delivery of products

PR5: Using e-retailing sites could lead to loss of privacy

\section{Factor-6: Perceived Enjoyment}

This factor contains four items- Item 16, Item 13, and Item 14, Item 15 explaining 5.174\% variance in the data, with the Eigen value of 1.811. The items associated with this factor are given below:

PEN1: E-retailing sites are interesting

PEN2: E-retailing sites are enjoyable

PEN3: E-retailing sites are exciting

PEN4: E-retailing sites are pleasant

\section{Factor-7: Perceived Ease of Use}

This factor contains three statements- Item 12, Item 8, and Item 9, Item 11, Item 7, Item 10 explaining 4.100\% variance in the data, with the Eigen value of 1.435. The items associated with this factor are given below:

PEU1: I find e-retailing sites easy to use

PEU2: I find it easy to get the e-retailing sites to do what I want it to do

PEU3: My interaction with e-retailing sites is clear and understandable

PEU4: It is easy for me to become skilful at using the e-retailing sites

PEU5: Learning to operate e-retailing sites was easy for me

PEU6: I find the e-retailing sites flexible to interact with 
Table-7:Test for Item total correlation and Internal reliability

\begin{tabular}{|c|c|c|c|}
\hline Factors & Items & Item total correlation & Cronbach's alpha \\
\hline \multirow{3}{*}{ Intention to Purchase Online } & INT1 & 0.70 & \multirow{3}{*}{0.79} \\
\hline & INT2 & 0.60 & \\
\hline & INT3 & 0.59 & \\
\hline \multirow{7}{*}{ Web Aesthetics } & WA1 & 0.65 & \multirow{7}{*}{0.83} \\
\hline & WA2 & 0.64 & \\
\hline & WA3 & 0.59 & \\
\hline & WA4 & 0.56 & \\
\hline & WA5 & 0.53 & \\
\hline & WA6 & 0.52 & \\
\hline & WA7 & 0.47 & \\
\hline \multirow{6}{*}{ Perceived Usefulness } & PU1 & 0.76 & \multirow{6}{*}{0.86} \\
\hline & PU2 & 0.76 & \\
\hline & PU3 & 0.71 & \\
\hline & PU4 & 0.72 & \\
\hline & PU5 & 0.57 & \\
\hline & PU6 & 0.47 & \\
\hline \multirow{4}{*}{ Attitude towards E-retailing } & ATT1 & 0.71 & \multirow{4}{*}{0.84} \\
\hline & ATT2 & 0.69 & \\
\hline & ATT3 & 0.57 & \\
\hline & ATT4 & 0.49 & \\
\hline \multirow{4}{*}{ Perceived Risk } & PR1 & 0.78 & \multirow{4}{*}{0.81} \\
\hline & PR2 & 0.63 & \\
\hline & PR3 & 0.61 & \\
\hline & PR4 & 0.55 & \\
\hline
\end{tabular}




\begin{tabular}{|c|c|c|c|}
\hline & PR5 & 0.42 & \\
\hline \multirow{4}{*}{ Perceived Enjoyment } & PEN1 & 0.85 & \multirow{4}{*}{0.87} \\
\hline & PEN2 & 0.86 & \\
\hline & PEN3 & 0.70 & \\
\hline & PEN4 & 0.54 & \\
\hline \multirow{6}{*}{ Perceived Ease of Use } & PEU1 & 0.69 & \multirow{6}{*}{0.86} \\
\hline & PEU2 & 0.68 & \\
\hline & PEU3 & 0.64 & \\
\hline & PEU4 & 0.64 & \\
\hline & PEU5 & 0.62 & \\
\hline & PEU6 & 0.65 & \\
\hline
\end{tabular}

From Table-7 it can be seen that, all the items are having item total correlation in excess of 0.40 which is the minimum acceptable limit for the same (Loiacono et al., 2002). Also, internal reliability (Cronbach's alpha) for all the factors are found to be in excess of 0.70 which is the minimum acceptable limit for the same (Nunnally, 1978). Hence, all the factors meet the conditions of item total correlation and internal reliability.

Table-8: Test for Composite Reliability

\begin{tabular}{|c|c|c|c|c|c|}
\hline Factors & Items & $\begin{array}{c}\text { Factor } \\
\text { loadings }(\lambda)\end{array}$ & $\lambda^{2}$ & $\begin{array}{l}\text { Error variance } \epsilon \\
\qquad=\left(1-\lambda^{2}\right)\end{array}$ & $\begin{array}{l}\text { Composite } \\
\text { reliability }\end{array}$ \\
\hline \multirow{3}{*}{$\begin{array}{c}\text { Intention to } \\
\text { Purchase } \\
\text { Online }\end{array}$} & INT1 & 0.844 & 0.712336 & 0.287664 & \multirow{3}{*}{0.83} \\
\hline & INT2 & 0.770 & 0.5929 & 0.4071 & \\
\hline & INT3 & 0.743 & 0.552049 & 0.447951 & \\
\hline \multirow{7}{*}{$\begin{array}{c}\text { Web } \\
\text { Aesthetics }\end{array}$} & WA1 & 0.845 & 0.714025 & 0.285975 & \multirow{7}{*}{0.90} \\
\hline & WA2 & 0.821 & 0.674041 & 0.325959 & \\
\hline & WA3 & 0.785 & 0.616225 & 0.383775 & \\
\hline & WA4 & 0.749 & 0.561001 & 0.438999 & \\
\hline & WA5 & 0.710 & 0.5041 & 0.4959 & \\
\hline & WA6 & 0.695 & 0.483025 & 0.516975 & \\
\hline & WA7 & 0.661 & 0.436921 & 0.563079 & \\
\hline \multirow[b]{3}{*}{ Perceived } & PU1 & 0.827 & 0.683929 & 0.316071 & \\
\hline & PU2 & 0.812 & 0.659344 & 0.340656 & \\
\hline & PU3 & 0.802 & 0.643204 & 0.356796 & \\
\hline
\end{tabular}




\begin{tabular}{|c|c|c|c|c|c|}
\hline \multirow[t]{3}{*}{ Usefulness } & PU4 & 0.799 & 0.638401 & 0.361599 & \multirow[t]{3}{*}{0.89} \\
\hline & PU5 & 0.692 & 0.478864 & 0.521136 & \\
\hline & PU6 & 0.581 & 0.337561 & 0.662439 & \\
\hline \multirow{4}{*}{$\begin{array}{l}\text { Attitude } \\
\text { Towards E- } \\
\text { retailing }\end{array}$} & ATT1 & 0.841 & 0.707281 & 0.292719 & \multirow{4}{*}{0.82} \\
\hline & ATT2 & 0.768 & 0.589824 & 0.410176 & \\
\hline & ATT3 & 0.686 & 0.470596 & 0.529404 & \\
\hline & ATT4 & 0.593 & 0.0 .351649 & 0.648351 & \\
\hline \multirow{5}{*}{ Perceived Risk } & PR1 & 0.879 & 0.772641 & 0.227359 & \multirow{5}{*}{0.85} \\
\hline & PR2 & 0.788 & 0.620944 & 0.379056 & \\
\hline & PR3 & 0.751 & 0.564001 & 0.435999 & \\
\hline & PR4 & 0.674 & 0.454276 & 0.545724 & \\
\hline & PR5 & 0.556 & 0.309136 & 0.690864 & \\
\hline \multirow{4}{*}{$\begin{array}{l}\text { Perceived } \\
\text { Enjoyment }\end{array}$} & PEN1 & 0.876 & 0.767376 & 0.232624 & \multirow{4}{*}{0.88} \\
\hline & PEN2 & 0.873 & 0.762129 & 0.237871 & \\
\hline & PEN3 & 0.796 & 0.633616 & 0.366384 & \\
\hline & PEN4 & 0.667 & 0.444889 & 0.555111 & \\
\hline \multirow{6}{*}{$\begin{array}{c}\text { Perceived Ease } \\
\text { of Use }\end{array}$} & PEU1 & 0.900 & 0.81 & 0.19 & \multirow{6}{*}{0.91} \\
\hline & PEU2 & 0.878 & 0.770884 & 0.229116 & \\
\hline & PEU3 & 0.823 & 0.677329 & 0.322671 & \\
\hline & PEU4 & 0.804 & 0.646416 & 0.353584 & \\
\hline & PEU5 & 0.643 & 0.413449 & 0.586551 & \\
\hline & PEU6 & 0.636 & 0.404496 & 0.595504 & \\
\hline
\end{tabular}

From Table-8 it can be seen that, all the factors are having composite reliability in excess of 0.70 which is the minimum acceptable limit for the same (Hair et al., 2014). Hence all the 7 factors meet the composite reliability condition.

Table-9: Test for Convergent Validity

\begin{tabular}{|c|c|c|c|c|c|}
\hline Factors & Items & $\begin{array}{c}\text { Factor loadings } \\
(\lambda)\end{array}$ & $\lambda^{2}$ & $\begin{array}{c}\text { Error variance } \boldsymbol{A} \\
=\left(1-\lambda^{2}\right)\end{array}$ & AVE* \\
\hline $\begin{array}{c}\text { Intention to } \\
\text { Purchase } \\
\text { Online }\end{array}$ & INT1 & 0.844 & 0.712336 & 0.287664 & \multirow{2}{*}{0.619} \\
\cline { 2 - 5 } & INT2 & 0.770 & 0.5929 & 0.4071 & \\
\cline { 2 - 5 } & INT3 & 0.743 & 0.552049 & 0.447951 & \\
\cline { 2 - 5 } & WA1 & 0.845 & 0.714025 & 0.285975 & \\
\cline { 2 - 5 } & WA2 & 0.821 & 0.674041 & 0.325959 & \\
\cline { 2 - 5 } & WA3 & 0.785 & 0.616225 & 0.383775 & \multirow{2}{*}{0.570} \\
\cline { 2 - 5 } Web & WA4 & 0.749 & 0.561001 & 0.438999 & \\
\cline { 2 - 5 } & WA5 & 0.710 & 0.5041 & 0.4959 & \\
\cline { 2 - 5 } & WA6 & 0.695 & 0.483025 & 0.516975 & \\
\cline { 2 - 5 } & WA7 & 0.661 & 0.436921 & 0.563079 & \\
\hline
\end{tabular}




\begin{tabular}{|c|c|c|c|c|c|}
\hline \multirow{6}{*}{$\begin{array}{l}\text { Perceived } \\
\text { Usefulness }\end{array}$} & PU1 & 0.827 & 0.683929 & 0.316071 & \multirow{6}{*}{0.574} \\
\hline & PU2 & 0.812 & 0.659344 & 0.340656 & \\
\hline & PU3 & 0.802 & 0.643204 & 0.356796 & \\
\hline & PU4 & 0.799 & 0.638401 & 0.361599 & \\
\hline & PU5 & 0.692 & 0.478864 & 0.521136 & \\
\hline & PU6 & 0.581 & 0.337561 & 0.662439 & \\
\hline \multirow{4}{*}{$\begin{array}{c}\text { Attitude } \\
\text { Towards E- } \\
\text { retailing }\end{array}$} & ATT1 & 0.841 & 0.707281 & 0.292719 & \multirow{4}{*}{0.530} \\
\hline & ATT2 & 0.768 & 0.589824 & 0.410176 & \\
\hline & ATT3 & 0.686 & 0.470596 & 0.529404 & \\
\hline & ATT4 & 0.593 & 0.351649 & 0.648351 & \\
\hline \multirow{5}{*}{$\begin{array}{c}\text { Perceived } \\
\text { Risk }\end{array}$} & PR1 & 0.879 & 0.772641 & 0.227359 & \multirow{5}{*}{0.544} \\
\hline & PR2 & 0.788 & 0.620944 & 0.379056 & \\
\hline & PR3 & 0.751 & 0.564001 & 0.435999 & \\
\hline & PR4 & 0.674 & 0.454276 & 0.545724 & \\
\hline & PR5 & 0.556 & 0.309136 & 0.690864 & \\
\hline \multirow{4}{*}{$\begin{array}{l}\text { Perceived } \\
\text { Enjoyment }\end{array}$} & PEN1 & 0.876 & 0.767376 & 0.232624 & \multirow{4}{*}{0.652} \\
\hline & PEN2 & 0.873 & 0.762129 & 0.237871 & \\
\hline & PEN3 & 0.796 & 0.633616 & 0.366384 & \\
\hline & PEN4 & 0.667 & 0.444889 & 0.555111 & \\
\hline \multirow{6}{*}{$\begin{array}{l}\text { Perceived } \\
\text { Ease of Use }\end{array}$} & PEU1 & 0.900 & 0.81 & 0.19 & \multirow{6}{*}{0.620} \\
\hline & PEU2 & 0.878 & 0.770884 & 0.229116 & \\
\hline & PEU3 & 0.823 & 0.677329 & 0.322671 & \\
\hline & PEU4 & 0.804 & 0.646416 & 0.353584 & \\
\hline & PEU5 & 0.643 & 0.413449 & 0.586551 & \\
\hline & PEU6 & 0.636 & 0.404496 & 0.595504 & \\
\hline
\end{tabular}

\section{*AVE- Average Variance Extracted}

From Table-9 it can be seen that, Average Variance Extracted for each of the 7 factors mentioned above are greater than the minimum acceptable 0.5 for the same. Hence, all the 7 factors meet the convergent validity condition (Fornell\&Larcker, 1981).

Table-10:Test for Discriminant validity

\begin{tabular}{|c|c|c|c|c|c|}
\hline Factors & $\begin{array}{c}\text { Correlation with } \\
\text { other Factors }\end{array}$ & $\begin{array}{c}\text { Correlation } \\
\text { coefficient }\end{array}$ & $\begin{array}{c}\text { Square of the } \\
\text { highest } \\
\text { correlation } \\
\text { coefficient } \\
\left(\mathrm{MSV}^{* *}\right)\end{array}$ & $\mathrm{AVE}^{*}$ & Remarks \\
\hline & $\mathrm{PU}<->\mathrm{PEU}$ & 0.118 & & & \\
\hline
\end{tabular}




\begin{tabular}{|c|c|c|c|c|c|}
\hline \multirow{5}{*}{$\begin{array}{l}\text { Perceived } \\
\text { Usefulness }\end{array}$} & $\mathrm{PU}<-->\mathrm{PEN}$ & 0.128 & \multirow{5}{*}{0.024} & \multirow{5}{*}{0.574} & \multirow{5}{*}{$\mathrm{MSV}<\mathrm{AVE}$} \\
\hline & $\mathrm{PU}<-->\mathrm{PR}$ & -0.151 & & & \\
\hline & $\mathrm{PU}<-->\mathrm{WA}$ & 0.103 & & & \\
\hline & $\mathrm{PU}<-->$ ATT & 0.154 & & & \\
\hline & $\mathrm{PU}<-->\mathrm{INT}$ & 0.112 & & & \\
\hline \multirow{6}{*}{$\begin{array}{l}\text { Perceived } \\
\text { Ease of Use }\end{array}$} & $\mathrm{PEU}<-->\mathrm{PU}$ & 0.118 & \multirow{6}{*}{0.172} & \multirow{6}{*}{0.620} & \multirow{6}{*}{$\mathrm{MSV}<\mathrm{AVE}$} \\
\hline & PEU <-- > PEN & 0.169 & & & \\
\hline & $\mathrm{PEU}<-->\mathrm{PR}$ & -0.197 & & & \\
\hline & PEU $<-->$ WA & 0.117 & & & \\
\hline & PEU $<-->$ ATT & 0.132 & & & \\
\hline & $\mathrm{PEU}<-->\mathrm{INT}$ & 0.415 & & & \\
\hline \multirow{6}{*}{$\begin{array}{l}\text { Perceived } \\
\text { Enjoyment }\end{array}$} & PEN $<-->$ PU & 0.128 & \multirow{6}{*}{0.143} & \multirow{6}{*}{0.652} & \multirow{6}{*}{$\mathrm{MSV}<\mathrm{AVE}$} \\
\hline & PEN <-- > PEU & 0.169 & & & \\
\hline & $\mathrm{PEN}<-->\mathrm{PR}$ & -0.209 & & & \\
\hline & $\mathrm{PEN}<-->\mathrm{WA}$ & 0.378 & & & \\
\hline & PEN $<-->$ ATT & 0.276 & & & \\
\hline & $\mathrm{PEN}<-->\mathrm{INT}$ & 0.205 & & & \\
\hline \multirow{6}{*}{$\begin{array}{c}\text { Perceived } \\
\text { Risk }\end{array}$} & $\mathrm{PR}<-->\mathrm{PU}$ & -0.151 & \multirow{6}{*}{0.018} & \multirow{6}{*}{0.544} & \multirow{6}{*}{$\mathrm{MSV}<\mathrm{AVE}$} \\
\hline & $\mathrm{PR}<-->\mathrm{PEU}$ & -0.197 & & & \\
\hline & $\mathrm{PR}<-->\mathrm{PEN}$ & -0.209 & & & \\
\hline & $\mathrm{PR}<-->\mathrm{WA}$ & -0.236 & & & \\
\hline & $\mathrm{PR}<-->\mathrm{ATT}$ & -0.277 & & & \\
\hline & $\mathrm{PR}<-->\mathrm{INT}$ & -0.135 & & & \\
\hline \multirow{6}{*}{$\begin{array}{c}\text { Web } \\
\text { Aesthetics }\end{array}$} & $\mathrm{WA}<-->\mathrm{PU}$ & 0.103 & \multirow{6}{*}{0.143} & \multirow{6}{*}{0.570} & \multirow{6}{*}{$\mathrm{MSV}<\mathrm{AVE}$} \\
\hline & $\mathrm{WA}<-->\mathrm{PEU}$ & 0.117 & & & \\
\hline & $\mathrm{WA}<-->\mathrm{PEN}$ & 0.378 & & & \\
\hline & $\mathrm{WA}<-->\mathrm{PR}$ & -0.236 & & & \\
\hline & WA $<-->$ ATT & 0.246 & & & \\
\hline & WA $<-->$ INT & 0.160 & & & \\
\hline \multirow{6}{*}{$\begin{array}{l}\text { Attitude } \\
\text { towards E- } \\
\text { retailing }\end{array}$} & ATT $<-->$ PU & 0.154 & \multirow{6}{*}{0.076} & \multirow{6}{*}{0.530} & \multirow{6}{*}{$\mathrm{MSV}<\mathrm{AVE}$} \\
\hline & ATT $<-->$ PEU & 0.132 & & & \\
\hline & ATT $<-->$ PEN & 0.276 & & & \\
\hline & $\mathrm{ATT}<-->\mathrm{PR}$ & -0.277 & & & \\
\hline & ATT $<-->$ WA & 0.246 & & & \\
\hline & ATT $<-->$ INT & 0.160 & & & \\
\hline \multirow{4}{*}{$\begin{array}{c}\text { Intention to } \\
\text { Purchase }\end{array}$} & INT $<-->$ PU & 0.112 & \multirow[b]{4}{*}{0.172} & \multirow[b]{4}{*}{0.619} & \\
\hline & INT $<-->$ PEU & 0.415 & & & \\
\hline & INT $<-->$ PEN & 0.205 & & & \\
\hline & INT $<-->$ PR & -0.135 & & & $\mathrm{MSV}<\mathrm{AVE}$ \\
\hline
\end{tabular}




\begin{tabular}{|l|l|l|l|l|l|}
\hline \multirow{2}{*}{ Online } & INT $<->$ WA & 0.160 & & & \\
\cline { 2 - 3 } & INT $<-->$ ATT & 0.160 & & & \\
\hline
\end{tabular}

*AVE- Average Variance Extracted

${ }^{* *}$ MSV- Maximum Shared Variance

From Table-10 it can be seen that, Average variance extracted of each of the factors is greater than the corresponding Maximum Shared Variance. Hence, all the 7 factors meet the divergent validity condition (Fornell\&Larcker, 1981).

\section{Findings:}

The 7 factors extracted using exploratory factor analysis, which include total 35 items, were tested for reliability and validity and all of them were found to have met the criteria. Hence, the constructs along with the items can be adopted for further study.

Based on the literature reviews and various tests, a conceptual model has been developed which is given below:

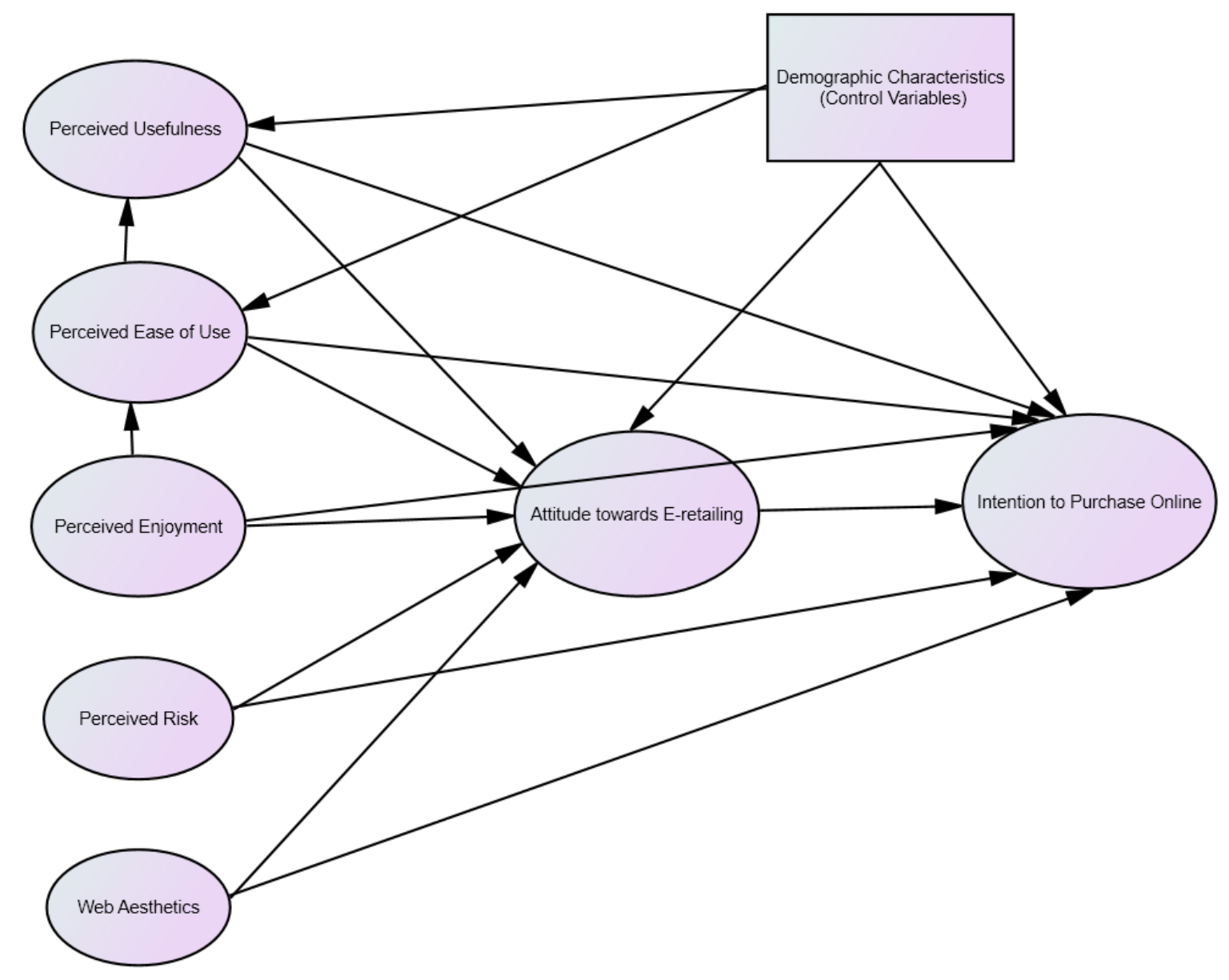

\section{Conceptual model}




\section{Limitations of the study}

The study was limited to the cities of Bhubaneswar and Kolkata in the eastern part of the country due to financial and time constraints. The vast and diverse culture of India which has a significant impact in shaping the behaviour of the citizens, makes it almost impossible to extrapolate the results to the entire country. Along with that, the relatively small number of samples can also pose a risk in implementing the conceptual model in the entire country. Despite of an elaborate literature review, all the possible factors couldn't be included in the conceptual model due to the fear of making the study excessively complex. Despite of all these limitations, this study is an honest attempt by the researchers to get some picture of various behavioural aspects of online shoppers.

\section{III.DISCUSSION AND CONCLUSION}

Consumer behaviour remains the single biggest riddle for the marketers. Every organization wants to accurately map consumer behaviour to maximize gains from their products and services. In that context, it is not only important for companies to produce quality products and services, but analysing the various behavioural aspects of consumers also become vital to effectively target them. Shopping using e-retailing websites take place in the virtual world where sellers and buyers never come face to face and hence analysing online consumer behaviour is a far bigger challenge than analyzing customers in a physical setup for sellers. This research work attempts to provide an online consumer behaviour model which sellers can effectively utilize to tap maximum gain from their customers. As already mentioned, a detailed study on online consumer behaviour in the Indian context is a rarity and hence can be of immense help for those millions of sellers who want to sell their commodities using the online medium.

\section{REFERENCES}

[1]. Al-Gahtani, S. S., \& King, M. (1999). Attitudes, Satisfaction and Usage: Factors Contributing to Each in the Acceptance of Information Technology. Behaviour and Information Technology, 18(4), 277-297

[2]. Alreck, P., \& Settle, R. B. (2002). Gender effects on internet, catalogue and store shopping. Journal of Database Marketing \& Customer Strategy Management, 9(2), 150-162

[3]. Armor, D. J. (1974). Theta Reliability and Factor Scaling. Sociological Methodology, 5, $17-50$
[4]. Burke, R. R. (2002). Technology and the Customer Interface: What Consumers Want in the Physical and Virtual Store. Journal of the Academy of Marketing Science, 30(4), 411-432

[5]. Cai, S., Xu, Y., Yu, J., \& De Souza, R. (2008, July 4-7). Understanding Aesthetics Design for Ecommerce Web sites: A Cognitive-Affective Framework. Paper presented at the Pacific Asia Conference on Information Systems, PACIS 2008, Suzhou, China

[6]. Chen, M. F. (2007). Consumer attitudes and purchase intentions in relation to organic foods in Taiwan: Moderating effects of food-related personality traits. Food Quality and Preference, 18(7), 1008-1021 
[7]. Chu, C. W., \& Lu, H. P. (2007). Factors Influencing Online Music Purchase Intention in Taiwan. Internet Research, 17(2), 139-155

[8]. Clemes, M. D., Gan, C., \& Zhang, J. (2014). An empirical analysis of e-retailing adoption in Beijing, China. Journal of Retailing and Customer Services, 21(3), 364-375

[9]. Costello, A. B., \& Osborne, J. W. (2005). Best Practices in Exploratory Factor Analysis: Four Recommendations for Getting the Most from Your Analysis. Practical Assessment Research and Evaluation, 10(7), 1-9

[10]. Cudeck, R., \& O’Dell, L. L. (1994). Applications of Standard Error Estimates in Unrestricted Factor Analysis: Significance Tests for Factor Loadings and Correlations. Psychological Bulletin, 115(3), 475-487

[11]. Davis, F. D. (1989, September). Perceived Usefulness, Perceived Ease of Use, and User Acceptance of Information Technology. MIS Quarterly, 13(3), 319-340

[12]. Davis, F. D., Bagozzi, R. P., \& Warshaw, P. R. (1989). User Acceptance of Computer Technology: A comparison of Two Theoretical Models. Management Science, 35(8), 982-1003

[13]. Davis, F. D., Bagozzi, R. P., \& Warshaw, P. R. (1992). Extrinsic and intrinsic motivation to use computers in the workplace. Journal of Applied Social Psychology, 22(14), 1111-1132

[14]. Dholakia, R. R., \& Uusitalo, O. (2002). Switching to Electronic Stores: Consumer Characteristics and the Perception of Shopping Benefits. International Journal of Retail and Distribution Management, 30(10), 459-469

[15]. Fabrigar, L. R., Wegener, D. T., MacCallum, R. C., \& Strahan, E. J. (1999). Evaluating the Use of Exploratory Factor Analysis in Psychological Research. Psychological Methods, 4(3), 272-299

[16]. Flavian, B. C., Gurrea, R. S., \& Orus, S. C. (2011). Gender Differences Regarding the
Product's Online Visual Representation: Impact on satisfaction and Purchase Intention. ESIC Market Economic and Business Journal, 38(1), 145-170

[17]. Fornell, C. G., \& Larcker, D. F. (1981). Evaluating Structural Equation Models with Unobservable Variables and Measurement Error. Journal of Marketing Research, 18(1), 3950

[18]. Fram, E. H., \& Grandy, D. B. (1997). Internet Shoppers: Is there a Surfer Gender Gap? Direct Marketing, 59(1), 46-50

[19]. Goldsmith, R. E., \& Goldsmith, E. B. (2002). Buying Apparel Over the Internet. Journal of Product and Brand Management, 11(2), 89-102

[20]. Gorsuch, R. L. (1983). Factor Analysis (2nd ed.). Hillsdale, NJ: Lawrence Erlbaum Associates

[21]. Hasan, B. (2010). Exploring Gender Differences in E-retailing Attitude. Computers in Human Behavior, 26(1), 597-601

[22]. Hirst, A., \& Omar, O. (2007). Assessing Women's Apparel Shopping Behaviour on The Internet. Journal of Retail Marketing Management Research, 1(1), 32-40

[23]. Huang, M. (2003). Modeling virtual exploratory and shopping dynamics: An environmental psychology approach. Information and Management, 41(1), 39-47

[24]. Iyer, R., \& Eastman, J. S. (2004). The Elderly's Uses and Attitudes Towards the Internet. Journal of Consumer Marketing, 21(3), 208-220

[25]. Jarvenpaa, S. L., \& Todd, P. A. (1997). Is there a future for retailing on the internet? In R. A. Peterson (Ed.), Electronic marketing and the consumer (pp. 139-154). Thousand Oaks, CA: SAGE publications Inc.

[26]. Jisoo, P. (2015). Improving User Interaction in Interactive TV Based on Ethnographic Insights from Real-life Problems. International Journal of Human-Computer Interaction, 31(1), 17-32 
[27]. Kaiser, H. F. (1960). The Application of the Electronic Computers to Factor Analysis. Educational and Psychological Measurement, 20(1), 141-151

[28]. Kaiser, H. F. (1974). An Index of Factorial Simplicity. Psychometrika, 39(1), 31-36

[29]. Karayanni, D. A. (2003). Web-Shoppers and Non-Shoppers: Compatibility, Relative Advantage and Demographics. European Business Review, 15(3), 141-152

[30]. Kim, E. B., \& Eom, S. B. (2002). Designing Effective Cyber Score Interface. Industrial Management and Data Systems, 102(5), 241251

[31]. Kline, P. (1994). An Easy Guide to Factor Analysis. New York, NY: Routledge

[32]. Koyunchu, C. \& Lien, D. (2003). E-Commerce and Consumer's Purchasing Behaviour. Applied Economics, 35(6), 721-726

[33]. Laroche, M. (2002). Selected Issues in Modeling Consumer Brand Choice: The Extended Competitive Vulnerability (Vol. 11, pp. 69114). Emerald Group Publishing Limited

[34]. Liao, Z., \& Shi, X. (2009). Consumer perceptions of internet-based e-retailing: An empirical research in Hong Kong. Journal of Services Marketing, 23(1), 24-30

[35]. Lindguard, G., \& Dudek, C. (2003). What is the Evasive Beast We Call User Satisfaction? Interacting with Computers, 15(3), 429-452

[36]. Lohse, G. L., Bellman, S., \& Johnson, E. J. (2000). Consumer Buying Behaviour on the Internet: Findings from Panel Data. Journal of Interactive Marketing, 14(1), 15-29

[37]. Loiacono, E. T., Watson, R. T., \& Goodhue, D. L. (2002). Webqual: A measure of Website Quality, Presented at American Marketing Association: Winter Marketing Educators' Conference, Chicago, 2002. Chicago, IL: American Marketing Association
[38]. Mangin, J. P., Bourgault, N., Guerrero, M. M., \& Egea J. M. (2011). Modeling Perceived Usefulness on Adopting Online Banking Through the TAM Model in a Canadian Banking Environment. Journal of Internet Banking and Commerce, 16(1), 1-23

[39]. McDonald, R. P. (1999). Test Theory: A Unified Treatment (1st ed.). Mahwah, NJ: Lawrence Erlbaum Associates Publishers

[40]. Nunnally, J. C. (1978). Psychometric Theory. New York, NY: McGraw-Hill

[41]. Osborne, J. W., \& Costello, A. B. (2009). Best Practices in Exploratory Factor Analysis: Four recommendations for Getting the Most from Your Analysis. Pan-Pacific Management Review, 12(2), 131-146

[42]. Peter, J. P., \& Tarpey, L. X. (1975). A Comparative Analysis of Three Consumer Decision Strategies. Journal of Consumer Research, 2, 215-224

[43]. Ramayah, T., \& Ignatius, J. (2005). Impact of perceived usefulness, perceived ease of use and perceived enjoyment on intention to shop online. The ICFAI Journal of Management Research, 3(3), 36-51

[44]. Sebastianelli, R., Tamimi, N., \& Rajan, M. (2008). Perceived Quality of E-retailing: Does Gender Make a Difference? Journal of Internet Commerce, 7(4), 455-469

[45]. Shim, S., Eastlick, M. A., Lotz, S. L., \& Warrington, P. (2001). An Online Pre Purchase Intentions Model: The Role of Intention to Search. Journal of Retailing, 77(3), 397-416

[46]. Sim, L. L., \& Koi, S. M. (2002). Singapore's Internet Shoppers and their Impact on Traditional Shopping Patterns. Journal of Retailing and Consumer Services, 9(1), 115-124

[47]. Sorce, P., Perotti, V., \& Widrick, S. (2005). Attitude and Age ifferences in Online Buying. 
International Journal of Retail and Distribution Management, 33(2), 122-132

[48]. Sultan, C., \& Henrichs, P. (2000). Community Level Socio-Economic Communication. Journal of Computer-Mediated Communication, 5(1), 13-22

[49]. Sun, H., \& Zhang, P. (2006). Causal Relationships between Perceived enjoyment and perceived ease of use: An alternative approach. Journal of the Association for Information Systems, 7(9), 618-645

[50]. Thogersen, J., \& Ölander, F. (2006). The Dynamic Interaction of Personal Norms and Environment-Friendly Buying Behaviour: A panel Study. Journal of Applied Social Psychology, 36(7), 1758-1780

[51]. Van der Heijden, H. (2003). Factors Influencing the Usage of Websites: The Case of a Generic Portal in the Netherlands. Information and Management, 40(6), 541-549

[52]. Van der Heijden, H. (2004). User Acceptance of Hedonic Information Systems. MIS Quarterly, 28(4), 695-704

[53]. Verplanken, B., Aarts, H., van Krippenberg, A., \& Moonen, A. (1998). Habit, Information Acquisition, and the Process of Making Travel Mode Choices. British Journal of Social Psychology, 37, 111-128

[54]. Vijayasarathy, L. R. (2001). The Impact of Shopping Orientations, Product Types, and Shopping Aids on Attitude and Intention to Use E-retailing. Quarterly Journal of Electronic Commerce, 2(2), 99-113

[55]. Zhao, H., \& Li, Y. (2012). Research on the influence of perceived risk in consumer online purchasing decision. Physics Procedia, 24, Proceeding of International Conference on Applied Physics and Industrial Engineering (pp. 1304-1310).
[56]. Zikmund, W. G., Bobin, B. J., Carr, J. C., \& Griffin, M. (2010). Business Research Methods (8th ed.). Mason, HO: Cengage Learning

\section{Cite this article as :}

Raja Sarkar, Dr. Sabyasachi Das, "A Conceptual Model to Measure the Impact of Consumer Behaviour on E-Retailing in India", International Journal of Scientific Research in Science and Technology (IJSRST), Online ISSN : 2395-602X, Print ISSN : 2395-6011, Volume 6 Issue 3, pp. 141-165, May-June 2019. Available at doi : https://doi.org/10.32628/IJSRST196329 Journal URL : http://ijsrst.com/IJSRST196329 